\title{
Intrauterine contraception after cesarean section and during lactation: a systematic review
}

This article was published in the following Dove Press journal:

International Journal of Women's Health

3 December 2013

Number of times this article has been viewed

\author{
Norman D Goldstuck' \\ Petrus S Steyn ${ }^{2}$ \\ 'Department of Obstetrics and \\ Gynaecology, Tygerberg Hospital, \\ Cape Town, Western Cape, South \\ Africa; ${ }^{2}$ Reproductive Health and \\ Fertility Regulation, Department of \\ Obstetrics and Gynaecology, Groote \\ Schuur Hospital and University of \\ Cape Town, Cape Town, South Africa
}

Correspondence: Norman D Goldstuck Department of Obstetrics and Gynaecology, Tygerberg Hospital, Francie van Zijl Avenue, Tygerberg, Cape Town, Western Cape 7505, South Africa

Tel +27 823418200

Email nahumzh@yahoo.com
Background: All postpartum women, including those who are breastfeeding or have had a cesarean section, appear potentially suited to intrauterine contraception, a long acting reversible contraceptive (LARC). Like any other method used after delivery, it should not interfere with lactation or be affected by cesarean section.

Study design: We searched the MEDLINE, PubMed, Popline, Google Scholar, and Clinicaltrials.gov databases from January 1968 through to December 2012. Studies were included if they reported event rates in women who had a cesarean section and event rates and clinical outcomes in lactating women or their infants in the breastfeeding group. Summary odds ratios were not calculated because of the diverse methods of reporting event rates in the cesarean section group and the heterogeneity of the results in the breastfeeding group.

Results: We found 26 articles on event rates in interval and post-placental intrauterine device (IUD) use, and 18 on event rates and clinical outcomes in breastfeeding IUD users. Four prospective studies and one retrospective study showed an increased expulsion rate in interval insertion. There were 19 studies, of which five were controlled in post-placental IUD insertion after cesarean section. Four studies had expulsion rates of 10 or more per 100 woman-years of use and 15 expulsion rates below 10 per 100 woman-years of use. Three studies showed that event rates for lactating IUD users are the same as those for non-lactating users. Fifteen controlled studies showed that the IUD had no effect on milk production and seven of these showed no effect on infant growth. Pharmacovigilance databases report an increased rate of IUD perforations in lactating women, while the event rate studies report that insertion is generally easier and less painful than expected. These were uncontrolled reports.

Conclusion: The IUD is a long-acting reversible method of contraception with expulsion rates of 5-15 per 100 woman-years of use when used as a post-placental method immediately after cesarean section. As an interval procedure (6 or more weeks after cesarean section) it appears to have a high expulsion rate ( $5 \%$ or higher) notably in older devices. The IUD does not affect breastfeeding and is easy to insert in these women, but appears to be associated with a higher perforation rate ( $>1$ per 100). Providers should not be deterred from using this contraception method, especially in developing countries, but should be attentive to preventing these potential problems.

Keywords: long acting reversible contraception, IUD, cesarean section, post-placental, lactation

\section{Introduction}

Developing countries tend to have high birth rates. ${ }^{1}$ In most cases, these countries are desirous of reducing them. The most effective contraceptive methods are the long acting reversible contraceptive (LARC) which are "forgettable" (user does not have to remember 
to take it). ${ }^{2}$ The importance of being able to breastfeed in all situations, and especially in underprivileged areas, is important for infant welfare. Women who are breastfeeding need to use a contraceptive method which has no effect on lactation. ${ }^{3}$ Women who have had a cesarean section (CS), whether for a current or previous pregnancy, also need a contraceptive method which is independent of this procedure. Lactation was used as a contraceptive before the advent of modern methods, and certain populations have used this method alone to space their children 3-4 years apart. ${ }^{4}$ During lactation, the suckling reflex inhibits ovulation. This is not mediated via prolactin, which inhibits ovulation at highly elevated levels due to pathological events, eg, pituitary tumors. ${ }^{4}$ During normal lactation, oxytocin-induced elevation of endorphins inhibits ovulation. ${ }^{4}$ In studies with primates, blocking this response with naloxone induces ovulation. ${ }^{4}$ Conversely, blocking prolactin activity with bromocriptine stops milk flow, but does not induce ovulation if the oxytocin endorphin pathway is maintained. ${ }^{4}$ It is important to ensure that the contraceptive method used in lactating women augments rather than diminishes lactation, and induces rather than inhibits whatever contraceptive activity lactation is providing.

This review examines the role of intrauterine contraception as a LARC method in these two conditions, and the role it can play in helping women to space out and adequately nourish their children, especially in underdeveloped countries and situations where continuing with lactation is paramount for infant health.

\section{Methods}

This study is a systematic review to evaluate possible complications in IUD users when inserted immediately after CS, and 6 weeks or longer after CS. It also evaluates the effect of lactation on IUD performance and vice versa, including the factors determining the lactatory response. The reference list for this study was generated from searching for references from the following databases:

MEDLINE: 'Intrauterine device (IUD, IUCD)'/ 'Intrauterine system (IUS) [MeSH]' and 'Cesarean section, caesarean section CS, C/S.' [MeSH]. 'Intrauterine device (IUD, IUCD)'/'Intrauterine system (IUS)' and 'Lactation' [MeSH].

POPLINE: 'IUD' and 'cesarean section'; 'IUD' and 'lactation'.

PubMed: 'IUD' and 'cesarean section'; 'IUD' and 'lactation'.

Google Scholar: 'IUD' and 'post placental cesarean section', and 'IUD' and 'interval cesarean section'; 'IUD' and 'lactation'; the terms were filtered so as not to overlap in the advanced search.
Clinical trials.gov: 'intrauterine device' AND 'cesarean section' and 'intrauterine device' AND 'lactation'.

We did not search Wangfang Data or Weipu Data, which refer to Chinese publications, as most large Chinese studies are available in the main databases. This is nevertheless a shortcoming, but the lack of referral to any Chinese studies other than the ones we found suggests there are not likely to be any other landmark studies in this area. Our study includes peer reviewed papers from January 1968 to December 2012. The search produced 1,145 papers in total, 317 for CS "post placental" and 62 for CS "interval", which was reduced to 262 and 44 after duplicates were eliminated. The search for "lactation" papers produced 828 papers, which was reduced to 592 excluding duplicates.

Only those papers which provided data which were directly referable to "cesarean section (caesarean section)" or "lactation" (assessed from the abstracts) were included, as the terms are used descriptively for subjects in very many IUD studies. The CS papers included only those which gave event rates (ie, analysis of IUD problems such as pregnancy, expulsion, pain and/or bleeding, and infection), expressed preferably by life table analysis, but also those which expressed data as a Pearl index or on a percentage basis. Controlled and uncontrolled studies were included. The same criteria applied to the lactation studies, but in addition studies were included which reported possible chemical changes due to the IUD on lactation. Studies of event rates required at least 20 subjects (one exception was made for a study of post-placental IUD insertion with 19). The studies of possible chemical changes due to IUD insertion were reported irrespective of the number of subjects. Event rates for both the $\mathrm{CS}$ and lactation studies were compared to controls whenever possible, and in one instance are tabulated separately. After imposition of these criteria there were 7 studies of interval IUD insertion post CS, 19 studies of post-placental IUD insertion after CS, 7 studies of the effect of IUDs on lactation chemistry, 14 studies on the effect of the IUD on lactation, and 3 studies on IUD event rates in lactating women. The effect of the IUD on lactation was also examined against controls whenever possible. The data were extracted by one author (NDG) and subsequently independently verified at a later date (PSS). Summary odds ratios were not calculated because of the variable methods of data reporting and some of the poorly quantifiable outcomes reported.

\section{Results}

\section{Cesarean section}

We found seven studies of interval insertion (ie, insertion at least 6 weeks after the last delivery, whether vaginal or by CS) of IUDs in women who had previously had one CS or more. ${ }^{5-11}$ 
There were five prospective and two retrospective studies. Five of the studies, including one retrospective, showed elevated expulsion results. Unfortunately, the methods of expression of event rates were both cumulative and non-cumulative, making comparison difficult. Pregnancy rates and device removal rates for medical problems were reported as being in the range of 0-5 per 100 woman-years of use.

The type of IUDs and number of subjects in each study is given in Table 1. There was one reported perforation, possibly due to a "hyperinvoluted" uterus. ${ }^{11}$ There was one study on Copper-T insertion in 76 women with previous cesarean section following surgical termination of pregnancy. ${ }^{12}$ The IUD was inserted post-abortum at 8-11 weeks. This study was controlled and the expulsion rate was $2.6 \%$. Since it was neither an interval nor a post-placental CS study, it does not appear in the table.

There were 19 studies of IUD insertion at the time of CS (post-placental cesarean IUD insertion) for which adequate data relative to the procedure is available. ${ }^{13-25}$ These studies have been carried out with different types of IUDs over the past 40 years. The studies were all prospective and most of the data is from the People's Republic of China and Latin America. A summary of the studies by device type is given in Table 2.

Five of the studies were controlled by comparing postpartum insertion after CS with insertion of the IUD in patients with normal vaginal deliveries. In all cases, the expulsion rate was lower in the CS group, and significantly lower in many cases. ${ }^{15,20,23,24}$ These studies are summarized separately in Table 3. Additionally, there are a few large, unpublished studies where details are sometimes quoted in the text as personal communications. The results from these observations were not used, as they did not meet the selection criteria. Some of the possible reasons for the large degree of variation in these results and the implications for post-placental IUD insertion after CS are discussed later.

\section{The effect of IUDs on lactation}

There have been numerous studies, both open and controlled, on the possible effect of IUDs on lactation itself,

Table I Interval IUD insertion after cesarean section

\begin{tabular}{|c|c|c|c|c|c|}
\hline Type of IUD & $\begin{array}{l}\text { Number } \\
\text { of subjects }\end{array}$ & $\begin{array}{l}\text { Time of } \\
\text { insertion }\end{array}$ & $\begin{array}{l}\text { Significant } \\
\text { event rate }\end{array}$ & Comments & Study \\
\hline $\left.\begin{array}{l}\text { Antigon I-45 } \\
\text { Antigon III-I7 } \\
\text { Antigon IV-29 } \\
\text { Antigon F-33 }\end{array}\right\}$ & 121 & 6-8 weeks & $\begin{array}{l}\text { Expulsion } 28.3^{*, e} \\
\text { Controls expulsion } \\
\text { I I.8\% }\end{array}$ & $\begin{array}{l}\text { Prospective, cumulative } \\
\text { per } 100 \text { woman years }\end{array}$ & Wiese $^{5}$ \\
\hline $\left.\begin{array}{l}\text { Lippes loop } \\
\text { Cu-T } \\
\text { Multiload }\end{array}\right\}$ & 318 & 6 weeks+ & Nil & $\begin{array}{l}\text { Retrospective pooled } \\
\text { Controlled }^{b}\end{array}$ & Chi and Balogh ${ }^{6}$ \\
\hline Cu-T 200 & 107 & 6 weeks & $\begin{array}{l}\text { Expulsion } 6.5 \% * \\
\text { Removals } 8.4 \% *\end{array}$ & $\begin{array}{l}\text { Prospective controlled } \\
\% \text {, not life table }\end{array}$ & Gupta et $\mathrm{al}^{7}$ \\
\hline $\left.\begin{array}{lr}\text { Dalkon shield } & 2 \\
\text { MLCu } 250 & 168 \\
\text { Copper } 7^{\circledR} & 22 \\
\text { Lippes loop }^{\circledR} & 7 \\
\text { Copper-T }^{\circledR} & 2 \\
\text { Not stated }^{2} & 14\end{array}\right\}$ & 215 & 6 weeks+ & Expulsion 19e & Retrospective cumulative rate, non-controlled ${ }^{d}$ & Holloway et $\mathrm{al}^{8}$ \\
\hline Szontagh IUD & 288 & Interval & 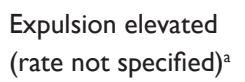 & $\begin{array}{l}\text { Controlled prospective cumulative rates } \\
\text { not expressed }\end{array}$ & Chi et $\mathrm{al}^{9}$ \\
\hline $\left.\begin{array}{l}\text { VCu } 200 \\
\text { TCu } 380 A\end{array}\right]$ & 400 & Interval & $\begin{array}{l}\text { Pregnancy } \\
\text { Removal }^{\square} \\
\text { Expulsion } \\
\text { VCu } 2000 \% \\
\text { TCu 380A 3.1\% }{ }^{a}\end{array}$ & $\begin{array}{l}\text { Prospective controlled VCu vs TCu } 380 \mathrm{~A} \\
\text { Event rates for both devices within accepted limits } \\
\text { Not cumulative }\end{array}$ & Tang and Feng ${ }^{10}$ \\
\hline Cu-T 200 & 45 & Interval & Expulsion $8.8 \%{ }^{a}$ & $\begin{array}{l}\text { Not life-table } \\
\text { I perforation } \\
\text { not controlled }\end{array}$ & $\begin{array}{l}\text { Parikh and } \\
\text { Gandhi' }\end{array}$ \\
\hline
\end{tabular}

Notes: $* P<0.05$ for study group versus control group; $\square \mathrm{P}<0.05$ for $\mathrm{VCu}(\mathrm{I} .02 \%)$ versus TCu $380 \mathrm{~A}(4.64 \%) ;{ }^{\diamond} \mathrm{P}<0.05$ for $\mathrm{VCu}(\mathrm{I} .02 \%)$ versus $\mathrm{TCu} 380 \mathrm{~A}(4.13 \%) ;{ }^{\bullet} \mathrm{P}<0.05$ for VCu (0\%) versus TCu 380A (3.1\%); 12 month follow up; '6 month follow up; ' 24 month follow up; ${ }^{d} 48$ month follow up; ${ }^{e} p e r$ I00 women years of use. Antigon (Svend Schroeder Co., Copenhagen, Denmark); Lippes Loop (Ortho Pharmaceutical, Raritan, NJ, USA); Dalkon shield (AH Robbins, Richmond, VA, USA); MLCu (Prosan S.A. Arnham, the Netherlands); Copper $7^{\circledR}$ (G.D.Searle and Co., High Wycombe, England, UK); Copper-T ${ }^{\circledR}$ (Ortho Pharmaceutical); Szontagh IUD (Semmelweiss University, Budapest, Hungary); VCu (Dr Y. Wu, Shanghai, People's Republic of China); TCu 380A (Teva Pharmaceutical Industries Ltd., Petach Tikva, Israel); Copper T 200 originally marketed by Ortho Pharmaceuticals, now replaced by TCU 380A of Teva Pharmaceutical Industries Ltd.

Abbreviation: IUD, intrauterine device; vs, versus. 
Table 2 Post-placental IUD insertions after cesarean section

\begin{tabular}{|c|c|c|c|c|c|c|}
\hline \multicolumn{7}{|c|}{ Event rate per 100 woman years (range) } \\
\hline Type of IUD & Studies & Subjects followed & Expulsion & Medical removal & Pregnancy & Comments and references \\
\hline Mirena ${ }^{\circledR}$ & 1 & 33 & 0 & 0 & 0 & 12 month follow up 13 \\
\hline MLCu 250 & 1 & 154 & $2.6 \%$ & $7.8 \%$ & 0 & 12 month percentage rate $\mathrm{r}^{14}$ \\
\hline TCu 220 & 3 & 714 & $(1.78-10.9)$ & Not stated & $0-1.1$ & 12 month cumulative rate ${ }^{15-17}$ \\
\hline TCu 380 & 5 & 314 & $(0-17.6)$ & $(0-10.6)$ & 0 & One study had 6 month follow up only ${ }^{18-22}$ \\
\hline Delta T & 2 & 135 & $(4.1-9.6)$ & 7.2 & 2.4 & ${ }^{\mathrm{a}}$ One reported 6 month cumulative, the \\
\hline Delta loop & & & & & & other 24 month percentage rates ${ }^{23,24}$ \\
\hline \multicolumn{7}{|l|}{ Delta Beijing } \\
\hline $\begin{array}{l}\text { Metal ring } \pm \\
\text { catgut knots }\end{array}$ & 7 & $3|3|$ & $(1.2-9.6)$ & $(0.8-7.2)$ & $(0-7.5)$ & ${ }^{\mathrm{a} C}$ Cumulative rate from 6-24 months $\mathrm{s}^{24,25}$ \\
\hline
\end{tabular}

Notes: ${ }^{a}$ Reference 24 reported 9 Chinese studies also reported in 23 and 25 . The data was only used once. Mirena ${ }^{\circledR}$ (Bayer, Wuppertal, Germany); MLCu 250 (Prosan S.A. Arnham, the Netherlands); TCu 380 (Teva Pharmaceutical Industries Ltd., Petach Tikva, Israel); Delta T, Delta loop, Delta Beijing, Metal ring (Chinese government, Beijing, People's Republic of China).

Abbreviation: IUD, intrauterine device.

and on the hormonal factors responsible for initiating and maintaining lactation. Following a report of reversible galactorrhea in two IUD users, ${ }^{26}$ a number of conflicting studies on the role of IUDs on prolactin, cortisol, and copper metabolism in lactating IUD users have been conducted. ${ }^{27-34}$

The results of these studies are summarized in Table 4. The consequences of the IUD altering prolactin levels in lactating women appear to be ephemeral at most. The IUD is a LARC method and if it is to be useful during lactation it is important that it shows no effect on inhibiting lactation. Unlike other LARC methods, its mechanism of action is not systemic (including the levonorgestrel intrauterine system). It should not be expected to have an effect on lactation (either positive or negative). Studies of lactation in women using the IUD confirm this. ${ }^{33,35-45}$

Additionally, the active agent (whether copper or levonorgestrel) should not adversely affect the quality of the milk as well as the quantity produced. The effect of the IUD on lactation and infant development in users has also been studied..$^{45-48} \mathrm{~A}$ summary of the studies confirming that there is no adverse effect on quantity and quality of milk production is given in Table 5.

\section{The effect of lactation on IUD performance}

Vaginal post-partum IUD insertion has its own complications. Whether lactation has a role at this stage cannot be demonstrated. The effect of established lactation on IUD insertion and performance from 6 weeks postdelivery is amenable to objective evaluation. There are three detailed studies using life table analysis on the effect of lactation on IUD performance, ${ }^{49-51}$ and these are given in Table 6 . Two of these $\mathrm{e}^{50,51}$ show a significantly increased medical removal rate for non-breastfeeders over those who were breastfeeding. The reasons for this may be that pain and bleeding is reduced in breastfeeders due to the full or partial lactational amenorrhea (LA) which reduces bleeding, and also the possible role of $\beta$-endorphin secretion in breastfeeding women. ${ }^{51} \beta$-endorphin is a powerful natural analgesic and would be expected to decrease all types of pain. Pregnancy rates and expulsion rates were

Table 3 Comparison of IUD expulsion rate after post-placental insertion following cesarean or vaginal delivery

\begin{tabular}{|c|c|c|c|c|}
\hline \multirow[t]{2}{*}{ Type of IUD } & \multirow[t]{2}{*}{ Subjects } & \multicolumn{2}{|c|}{ Expulsion rate } & \multirow[t]{2}{*}{ Comments and reference } \\
\hline & & PPCS & PPV & \\
\hline TCu 220 & 554 & 10.9 & $16.4^{\mathrm{a}}$ & 3 month cumulative ${ }^{15}$ \\
\hline TCu 380A & 19 & 0 & $50^{b}$ & Ultrasound detection cumulative at 12 months ${ }^{20}$ \\
\hline Delta $T$ & 52 & 4.1 & $20.5^{b}$ & 6 month cumulative 23,24 \\
\hline \multicolumn{5}{|l|}{ Delta loop } \\
\hline Delta T 24 & 83 & 3.9 & 7.5 & Catgut strings on IUDs cumulative at 12 months ${ }^{24}$ \\
\hline \multicolumn{5}{|l|}{ Delta loop 26} \\
\hline \multicolumn{5}{|l|}{ Delta Beijing 33} \\
\hline Metal ring \pm 3 catgut knots & 906 & 5.5 & 23.5 & Cumulative at 12 months ${ }^{24}$ \\
\hline
\end{tabular}

Notes: ${ }^{\mathrm{P}}<0.05$; ${ }^{\mathrm{b}} \mathrm{P}<0.00 \mathrm{I}$. TCu 380 (Teva Pharmaceutical Industries Ltd., Petach Tikva, Israel); Delta T, Delta loop, Delta T 24, Delta Beijing, Metal ring (Chinese Government, Beijing, People's Republic of China).

Abbreviations: IUD, intrauterine device; PPCS, post-placental insertion after cesarean section; PPV, post-placental insertion after vaginal delivery. 
Table 4 Prolactin levels in IUD users

\begin{tabular}{llll}
\hline Type of IUD & Subjects & $\begin{array}{l}\text { Prolactin } \\
\text { levels }\end{array}$ & $\begin{array}{l}\text { Comments } \\
\text { and reference }\end{array}$ \\
\hline Lippes loop & 6 & $\begin{array}{l}\text { Increase after } \\
\text { insertion } \\
\text { Increase after } \\
\text { insertion }\end{array}$ & $\begin{array}{l}\text { Normalized } \\
\text { next cycle }\end{array}$ \\
$\begin{array}{l}\text { Lippes loop C } \\
\text { Galactorrhea } \\
\text { reversed after } \\
\text { removal }\end{array}$ \\
Lactating and $^{26}$ \\
$\begin{array}{l}\text { Copper 7 } \\
\text { Copper-T }\end{array}$ \\
$\begin{array}{l}\text { Soonawalla YCu } \\
\text { non-lactating }\end{array}$
\end{tabular}

Notes: Lippes Loop (Ortho Pharmaceutical, Raritan, NJ, USA); Copper $7^{\circledR}$ (G.D.Searle and Co., High Wycombe, England, UK); Copper-T ${ }^{\circledR}$ (Ortho Pharmaceutical); Soonawalla YCu (Prof RPSoonawala, Indian Council of Medical Research, Mumbai, India); Progestasert (Alza Corporation, Palo Alto, CA, USA). Copper T 200 originally marketed by Ortho Pharmaceuticals, now replaced by TCU 380A of Teva Pharmaceutical Industries Ltd. Abbreviation: IUD, intrauterine device.

not significantly different for those who were breastfeeding and those who were not.

\section{Discussion}

A number of large studies have noted that IUD insertion is relatively easy and pain free in women who are lactating, and that lactation reduces the need for cervical dilation. ${ }^{51}$ A study of 6493 women also found that this was especially pronounced in women with lactational amenorrhea; ie, currently breastfeeding, which would be expected in the presence of increased $\beta$-endorphin levels, which also makes insertion less painful. ${ }^{50,52}$ The force required to insert an IUD in lactating women is also lower than in non-lactating women for the Copper- $\mathrm{T}^{\circledR}$ (Ortho Pharmaceuticals, Raritan, NJ, USA), TCu 380A, ParaGard ${ }^{\circledR}$, (Teva Pharmaceutical Industries Ltd., Petach Tikva, Israel), MLCu $250^{\circledR}, 375^{\circledR}$ (Prosan S.A., Arnham, the Netherlands), and Nova-T $200^{\circledR}$ (Bayer, Wuppertal, Germany) IUDs. ${ }^{53}$

The risk of perforation during IUD insertion in women who are lactating is increased approximately 10 fold. This was reported in a study of the Lippes loop (Ortho Pharmaceutical, Raritan, NJ, USA), Copper $7^{\circledR}$ (G.D. Searle and Co., High Wycombe, England, UK), Dalkon shield ${ }^{\circledR}$ (A.H. Robins Company, Richmond, VA, USA), Safe-T-Coil ${ }^{\circledR}$ (Julius Schmidt Laboratories, Little Falls, NJ, USA), Copper-T ${ }^{\circledR}$, and Progestasert ${ }^{\circledR}$ (Alza Corporation, Palo Alto, CA, USA) devices. ${ }^{52}$ The reported rate of perforation has been quoted as being from 1 in 350, to 1 in 2,600 insertions. ${ }^{54,55}$ Lactation also appears to be a major factor in perforations with the Mirena ${ }^{\circledR}$ (Bayer, Wuppertal, Germany). Of 701 perforations reported by pharmacovigilance centers, 192 (42\%) were in Mirena ${ }^{\circledR}$ users who were breastfeeding at the time. ${ }^{56}$

The reasons for the high rate of expulsion in interval IUD insertions after CS are not apparent. Five of seven studies of interval IUD insertion in women who had previously undergone CS showed elevated expulsion rates. These studies were mainly on older devices; there was no information on the

Table 5 The effect of the IUD on lactation

\begin{tabular}{|c|c|c|c|c|}
\hline Type of IUD & Studies & Subjects & Observations and results & Comments and references \\
\hline Lippes loop D & 1 & 185 & $\begin{array}{l}\text { No change in duration of lactation and amenorrhea } \\
\text { versus controls }\end{array}$ & PPV insertion ${ }^{35}$ \\
\hline Progestasert & 2 & 100 & $\begin{array}{l}\text { Quantity and quality of milk significantly higher } \\
\text { versus controls }\end{array}$ & PPV insertion ${ }^{37,38}$ \\
\hline TCu 380A & 133 & 62 & No increased copper in milk & 33 \\
\hline TCu 200B & 29] & & & \\
\hline Mirena ${ }^{\circledR}$ & 1 & 163 & $\begin{array}{l}\text { No changes in lactation or infant development } \\
\text { versus TCu 380A }\end{array}$ & $\begin{array}{l}\text { I57 in TCu } 380 \text { A group insertion } 6-8 \text { weeks } \\
\text { post-partum }{ }^{46}\end{array}$ \\
\hline TCu 380A & 2 & 831 & No change in lactation versus progesterone vaginal ring & 42,43 \\
\hline LNG - IUD & 2 & 90 & $\begin{array}{l}\text { Milk production and infant development same as controls } \\
\text { LNG in breast milk } 0.1 \% \text { of daily serum level }\end{array}$ & $\begin{array}{l}10 \text { ug and } 30 \text { ug releasing IUDs inserted } \\
6 \text { weeks post-partum } \\
39,47\end{array}$ \\
\hline$C u-I U D$ & $\mathrm{I}$ & 38 & $\begin{array}{l}\text { No change in volume and composition of breast milk } \\
\text { versus Implanon }\end{array}$ & $\begin{array}{l}\text { Insertion } 6 \text { weeks post-partum. IUD type not } \\
\text { specified }^{48}\end{array}$ \\
\hline $\mathrm{Cu}-\mathrm{IUD}$ & 1 & 68 & No alteration of duration of lactation or LAM & Interval insertion DMPA and POP controls ${ }^{36}$ \\
\hline MLCu 250 & 3 & 169 & $\begin{array}{l}\text { No change in milk quality and quantity and infant } \\
\text { development }\end{array}$ & $\begin{array}{l}\text { Interval insertion comparison with POP and } \\
\text { DMPA }^{38,40,41}\end{array}$ \\
\hline MLCu 375 & 1 & 41 & No change in milk quality and infant development & Interval insertion comparison with $\mathrm{POP}^{45}$ \\
\hline
\end{tabular}

Notes: Lippes Loop (Ortho Pharmaceutical, Raritan, NJ, USA); Progestasert (Alza Corporation, Palo Alto, CA, USA); TCu 380 (Teva Pharmaceutical Industries Ltd., Petach Tikva, Israel); Mirena ${ }^{\circledR}$ (Bayer, Wuppertal, Germany); MLCu (Prosan S.A., Arnham, the Netherlands).

Abbreviations: IUD, intrauterine device; DMPA, depo-medroxyprogesterone acetate; PPV, post-placental vaginal; LAM, lactational amenorrhea; LNG, levonorgestrel; POP, progestogen only pills. 
Table 6 IUD event rates in breastfeeding women

\begin{tabular}{llllll}
\hline Type of IUD & Subjects & Expulsion & \multicolumn{3}{l}{ Event rates per 100 woman years } \\
\cline { 3 - 6 } & & & Medical removal & Pregnancy & Comments and references \\
\hline Lippes loop D & 173 & $3.4^{\mathrm{a}}$ & $0.6^{\mathrm{a}}$ & $0.0^{\mathrm{a}}$ & 3 month rate interval insertion \\
Copper-T & & $2 . \mathrm{I}^{\mathrm{a}}$ & $0.0^{\mathrm{a}}$ & $0.0^{\mathrm{a}}$ & 3 month rate interval insertion \\
TCu 380A & 109 & $13^{\mathrm{a}}$ & $0.9^{\mathrm{b}}$ & $\mathrm{I}^{\mathrm{a}}$ & $\begin{array}{l}\text { No distinction between interval and PPV } \\
\text { insertions } 6 \text { month rate }\end{array}$ \\
TCu 380A & 590 & & & & 12 month rate all interval insertions \\
\hline
\end{tabular}

Notes: ${ }^{2}$ Not significant versus non breastfeeding; ${ }^{\mathrm{b}} \mathrm{P}<0.05$ versus non breastfeeding (significantly lower than non-breastfeeders). Lippes Loop (Ortho Pharmaceutical, Raritan, NJ, USA); Copper $7^{\oplus}$ (G.D.Searle and Co., High Wycombe, England, UK); TCu 380 (Teva Pharmaceutical Industries Ltd., Petach Tikva, Israel).

Abbreviations: IUD, intrauterine device; PPV, post-partum vaginal insertion.

Mirena $^{\circledR}$, Nova-T ${ }^{\circledR}$ and Gyne-Fix ${ }^{\circledR}$ (Contrel Limited, Ghent, Belgium) IUDs, which are in common use today, and limited information on the $\mathrm{TCu} 380 \mathrm{~A}^{\circledR}$, the current benchmark for copper-containing IUDs. It would be interesting to determine the attitude of inserters to see if there is any variation in their practical technique. Alternatively, it may be possible that the uterine scar is a factor, as it is in vaginal birth after CS (VBAC). A wealth of information on this topic exists in many databases. It would be worthwhile to extract and re-examine this data.

The variation in expulsion rates after post-placental CS can be explained by the large number of different devices and techniques used. Some promising ideas are already being evaluated, so this should become a highly viable option.

The CS rate is increasing worldwide and very rapidly in some countries. ${ }^{57}$ While the rate itself might be lower in most developing countries, the absolute numbers are high because of the high birth rates. In addition, the need for women to breastfeed in these countries is especially important because of the limited financial ability to use infant feeding formulas and to use them adequately when they are adopted.

For these women to be able to space their families adequately, it is important that they are able to use a LARC method which does not interfere with breastfeeding or breast milk, is cost-effective, and the use of which does not conflict with some of the consequences of childbirth, eg, CS.

There is no one reversible birth control method, short or long-acting, which is perfect in this regard. The IUD comes fairly close to this, with a few provisos. LARC methods should be introduced as soon after delivery as possible, and certainly before the mother leaves the facility because of the problems of follow up. The problems of the post-placental insertion of IUDs after vaginal births are well known, in particular, premature device expulsion.

Fortunately, the rates of expulsion after CS post-placental insertions appear to be significantly lower than when the IUD is used immediately after vaginal birth following delivery of the placenta, making insertion of IUDs immediately after $\mathrm{CS}$ this a much more viable option. There are many reasons for this and the design of IUDs especially for this purpose should both solve the expulsion problem and make this a very practical LARC method.

In order not to deprive women who have had previous cesarean deliveries of the IUD, we suggest that extra care should be taken in these subjects to ensure fundal IUD placement. Puerperal insertion also requires expertise to avoid these excessive expulsions. ${ }^{3}$ The newer IUDs may be less likely to be associated with some of these problems, and that is a subject for further examination.

Earlier studies suggesting that the IUD could raise prolactin levels ${ }^{26,34}$ and possibly affect lactation have not been confirmed. Both the current copper-releasing and hormonereleasing IUDs appear to have no effect on the quantity, quality, and duration of breastfeeding. In lactating women, IUD event rates of expulsion, pregnancy, and medical removal are not adversely different from non-lactating women, with the exception that medical removal rates are lower. ${ }^{51}$ Numerous studies have shown that insertion of IUDs in lactating women requires less cervical dilation and lower force to actually place the device. This is probably due to higher circulating $\beta$-endorphin levels and the softer consistency of lactating and especially puerperal uterine muscle. These factors may make insertion easier, but they also make perforation more likely since the inserter will perceive less resistance to insertion and the acceptor will experience less pain during the procedure. A previous CS and the presence of lactation require careful attention to detail to avoid the problems of expulsion and perforation, respectively. Despite these problems, neither a previous CS nor lactation is a World Health Organization contraindication to IUD insertion. ${ }^{58}$

\section{Conclusion}

Women who have had a CS and/or are breastfeeding are good candidates for intrauterine contraception such as LARCs. Post-placental CS IUD insertion is especially valuable as it appears to present fewer problems than after vaginal delivery. While IUDs do not affect lactation, and insertion of an IUD in 
lactating women is generally less painful and better tolerated, there are still attendant risks, such as perforation.

In women who have previously had a CS, IUD use in the presence of uterine scar appears to be associated with a higher risk of expulsion. Both these groups of women may use the IUD as a LARC method in appropriate circumstances. Extra care should be taken when placing IUDs in these women in order to try and mitigate potential IUD related problems.

\section{Disclosure}

This study was not funded by any external source. Norman D Goldstuck has never received funds or gifts in kind from any outside agency. Petrus S Steyn has lectured for various pharmaceutical companies. The authors report no other conflicts of interest in this work.

\section{References}

1. Cohen JE. Human population: the next half century. Science. 2003;302(5648):1172-1175.

2. Winner B, Peipert JF, Zhao Q, et al. Effectiveness of long-acting reversible contraception. N Eng J Med. 2012;366(21):1998-2007.

3. Saarikosi S. Contraception during lactation. Ann Med. 1993;25(2): 181-184.

4. Short RV. Breastfeeding. Sci Am. 1984;250(4):35-41.

5. Wiese J. A study of four Antigon models and factors in use-effectiveness of the IUD. Contraception. 1976;14(6):687-701.

6. Chi IC, Balogh S. Interval insertion of intrauterine device in women with previous cesarean section. Contraception. 1984;30(3):209-214.

7. Gupta I, Mahajan U, Lata P, Gupta AN. Copper intrauterine contraceptive device insertion 6 weeks after caesarean section. Indian J Med Res 1985;82:214-216.

8. Holloway GA, Goldstuck ND, Bowen D. Interval insertion of an intrauterine contraceptive device following cesarean section. Int J Gynecol Obstet. 1989;29(3):243-248.

9. Chi IC, Zhou SW, Balogh S, Ng K. IUD insertions following cesarean deliveries examined. 1983; 111th Annual Meeting of the American Public Health Association.

10. Tang YH, Feng ZJ. [Comparative study of clininical effects of $\mathrm{VCu}$ IUD and TCu 380A IUD were used on women who once been done caesarean section]. Zhonghua Yi Xue Za Zhi. 2012;92(17):1209-1211. Chinese.

11. Parikh V, Gandhi AS. Safety of copper-T as contraceptive after caesarean section. J Indian Med Assoc. 1989;87(5):113-115.

12. Gupta I, Mahajan U, Sawney H. Concurrent copper T insertion with medical termination of pregnancy in women with previous caesarean section delivery. Indian J Med Res. 1988;87:450-452.

13. Puzey M. Mirena at caesarean section. Eur J Contracept Reprod Health Care. 2005;10(3):164-167.

14. Ruiz - Velasco V, Garcia C, Castro H. Cesarean section IUD insertion. Contracept Deliv Syst. 1982;3(1):21-24.

15. Lara R, Sanchez RA, Aznar R. [Application of intrauterine device through the incision of the cesarean section]. Aplicacion del dispositivo intrauterino a traves de la incision de la cesarea. Ginecol Obstet Mex. 1989;57:23-27. Spanish.

16. Alvarez Pelago J, Borbolla Sala ME. [IUD insertion during cesarean section and its most frequent complications]. DIU transcesarea y sus complicaciones mas frecuentes. Ginecol Obstet Mex. 1994;62:330-335. Spanish.

17. Van Kets H, Thiery M, Van der Pas H. IUD insertion during cesarean section. Adv Contracept. 1985;1(4):337-339.
18. Celen S, Sucak A, Yildez Y, Danisman N. Immediate postplacental insertion of an intrauterine contraceptive device during cesarean section. Contraception. 2011;84(3):240-243.

19. Nelson AL, Chen S, Eden R. Intraoperative placement of the CopperT-380 intrauterine device in women undergoing elective cesarean delivery: a pilot study. Contraception. 2009;80(1):81-83.

20. Letti Müller AL, Lopes Ramos JG, Martins-Costa SH, et al. Transvaginal ultrasonographic assessment of the expulsion rate of intrauterine devices inserted in the immediate postpartum period: a pilot study. Contraception. 2005;72(3):192-195.

21. Levi E, Cantillo E, Ades V, Banks E, Murthy A. Immediate postplacental IUD insertion at caesarean delivery: a prospective cohort study. Contraception. 2012;86(2):102-105.

22. Celen S, Moroy P, Sucak A, Aktulay A, Danisman N. Clinical outcomes of early postplacental insertion of intrauterine contraceptive devices. Contraception. 2004;69(9):279-282.

23. Chi IC, Su-Wen Z, Balogh S, Ng K. Post-cesarean section insertion of intrauterine devices. Am J Pub Health. 1984;74(11):1281-1282.

24. Chi IC, Gao JI, Siemens AJ, Waszak CS. IUD insertion at cesarean section - the Chinese experience. Adv Contracept. 1986;(2):145-145.

25. Liu BH, Zhang LY, Zhang BR. Intrauterine contraceptive device insertion with suture fixation at cesarean section. Chin Med J. 1983;96(2): $141-144$.

26. Horn H, Finkelstein M, Ben-David M. Possible effect of intrauterine device on galactorrhoea in women. Contraception. 1975;12(4): 419-424.

27. Spellacy WN, Buhi WC. A prospective study of plasma prolactin levels in women using the progesterone releasing intrauterine device (P-IUD). Contraception. 1979;19(1):91-94.

28. Mehta S, Pawar V, Joshi J, et al. Serum prolactin levels in women using copper IUDs. Contraception. 1977;15(3):327-334.

29. Ransom WTM, Chapman RS, Hull MGR. Serum prolactin concentrations related to copper or inert intrauterine devices (IUDs) in women. Contraception. 1979;20(5):441-446.

30. Wenof M, Aubert JM, Reyniak JV. Serum prolactin levels in shortterm and long-term use of inert plastic and copper intrauterine devices. Contraception. 1979;19(1):21-27.

31. Askalani H, Badraoui MH, Mahrous I, et al. Serum cortisol level in women using the Progestasert system. Contracept Deliv Syst. 1981;2(1):133-138.

32. Badraoui MH, Askalani H, Mahrous I, et al. Serum-prolactin in lactating women using the Progestasert system. Contracept Deliv Syst. 1981;2(1): 121-126.

33. Rodrigues da Cunha AC, Doren JG, Cantuaria AA. Intrauterine device and maternal copper metabolism during lactation. Contraception. 2001;63(1):37-39.

34. Fortuny A, Pajol-Amat P, Calaf J, Mackinnon PCB, Robyn C. Plasma levels of $\mathrm{LH}, \mathrm{FSH}$ and prolactin in women during and after insertion of an intrauterine device. J Reprod Fert. 1973;35:628-629.

35. Hingorani V, Uma Bai GR. Lactation and lactational amenorrhoea with post-partum IUCD insertions. J Reprod Fert. 1970;23:513-515.

36. Prema K. Duration of lactation and return of menstruation in lactating women using hormonal contraception and IUDs. Contracept Deliv Syst. 1982;3(1):39-46.

37. Badraoui MH, Askalani H, Mahrons H, Serour G, Hefnawi F. Lactation pattern in Egyptian women using the Progestasert system. Contracept Deliv Syst. 1982;3(1):53-60.

38. Badraoui MH, Hefnawi F, Bahgat R, et al. Contraception during lactation. Reproduccion. 1982;6:9-18.

39. Heikkila M, Haukkamaa M, Luukainen T. Levonorgestrel in milk and plasma of breastfeeding women with a levonorgestrel-releasing IUD. Contraception. 1982;25(1):41-49.

40. Delgado Betancourt J, Sandoval JC, Sanchez F, Vallesteros De Cano P, De La Luz Bantista M, Jimenez F. Influence of Exluton (progestogenonly OC) and the Multiload Cu 250 IUD on lactation. Contracept Deliv Syst. 1984;5(1):91-95. 
41. Sinchai W, Sethavanich S, Asavapiriyanont S, et al. Effects of a progestogen-only pill (Exluton) and an intrauterine device (Multiload Cu250) on breastfeeding. Adv Contracept. 1995;11(2):143-155.

42. Chen JH, Wu SC, Shao WQ, et al. The comparative trial of TCu 380A IUD and progesterone releasing vaginal ring used by lactating women. Contraception. 1998;57(6):371-379.

43. Sivin I, Díaz S, Croxatto HB, et al. Contraceptives for lactating women: a comparative trial of a progesterone-releasing vaginal ring and the copper T 380A IUD. Contraception. 1997;55(4):225-232.

44. Laukaran VH. Contraceptive choices for lactating woman: suggestions for postpartum family planning. Stud Fam Plan. 1981;12(4):156-163.

45. Bjarnadottir RI, Gottfredsdottir H, Sigurdardottir K, Geirsson RT, Dieben TO. Comparative study of the effects of a progestogen-only pill containing desogestrel and an intrauterine contraceptive device in lactating women. BJOG. 2001;108:1174-1180.

46. Shaamash AH, Sagen GH, Hussein MH, Shaaban MM. A comparative study of the levonorgestrel - releasing intrauterine system Mirena versus the Copper T 380A intrauterine device during lactation: breastfeeding performance, infant growth and infant development. Contraception. 2005;72(5):346-351.

47. Heikkila M, Luukainen T. Duration of breastfeeding and development of children after insertion of a levonorgestrel-releasing intrauterine contraception device. Contraception. 1982;25(3):279-292.

48. Taneepanichskul S, Reinprayoon D, Thaithumyanon P, Praisuwana P, Tosukhowong P, Dieben T. Effects of the etonogestrel - releasing implant Implanon and a non-medicated intrauterine device on the growth of breast-fed infants. Contraception. 2006;73(4):368-371.

49. Cole LP, McCann M, Higgins JE, Waszak CS. Effects of breastfeeding on IUD performance. Am J Pub Health. 1983;73(4):384-388.
50. Chi IC, Potts M, Wilkens LR, Champion CB. Performance of the Copper T-380A intrauterine device in breastfeeding women. Contraception. 1989;39(6):603-618.

51. Farr G, Rivera R. Interactions between intrauterine contraceptive device and breast-feeding status at time of intrauterine contraceptive device insertion: analysis of TCu 380A acceptors in developing countries. Am J Obstet Gynecol. 1992;167(1):144-151.

52. Chi IC, Wilkens LR, Champion CB, Machemer RE, Rivera R. Insertion pain and other IUD insertion-related rare events for breastfeeding and non breastfeeding woman - a decade's experience in developing countries. Adv Contracept. 1989;2(5):101-119.

53. Goldstuck ND, Holloway G. IUD insertion forces: effects of recent childbirth and lactation. Adv Contracept. 1988;4(2):159-169.

54. Chi IC, Kelly E. Is lactation a risk factor of IUD - and sterilization related perforation? A Hypothesis. Int J Gynecol Obstet. 1984;22(4): 315-317.

55. Heartwell SF, Schlesselman S. Risk of uterine perforation among users of intrauterine devices. Obstet Gynecol. 1983;61(1):31-36.

56. Van Grootheest K, Sachs B, Harrison-Woolrych M, Caduff - Janosa P, van Puijenbroek E. Uterine perforation with the levonorgestrel releasing intrauterine device: analysis of reports from four national pharmacovigilance centres. Drug Saf. 2011;34(1):83-88.

57. Roberts CL, Algert CS, Ford JB, Todd AL, Morris JM. Pathways to a rising caesarean section rate: a population-based cohort study. BMJ Open. 2012;2(5):e001725.

58. World Health Organization. Selected practice recommendations for contraceptive use. 2nd edition. 2008. Available from: http://www.who. int/reproductivehealth/publications/en/. Accessed November 4, 2013.
International Journal of Women's Health

\section{Publish your work in this journal}

The International Journal of Women's Health is an international, peerreviewed open-access journal publishing original research, reports, editorials, reviews and commentaries on all aspects of women's healthcare including gynecology, obstetrics, and breast cancer. The manuscript management system is completely online and includes

\section{Dovepress}

a very quick and fair peer-review system, which is all easy to use. Visit http://www.dovepress.com/testimonials.php to read real quotes from published authors. 